\title{
Correction to: Bioactive compounds and antioxidant activities of Quercus salicina Blume extract
}

\author{
Thinzar Aung ${ }^{1}$ Marie Anna Dominique Bibat ${ }^{1} \cdot$ Chang-Cheng Zhao $^{1}$. \\ Jong-Bang $\operatorname{Eun}^{1}{ }^{1}$
}

(C) The Author(s) 2020

\section{Correction to: \\ Food Sci Biotechnol (2020) 29(4):449-458 https://doi.org/10.1007/s10068-020-00755-1}

The article "Bioactive compounds and antioxidant activities of Quercus salicina Blume extract", written by Thinzar Aung, Marie Anna Dominique Bibat, Chang-Cheng Zhao and Jong-Bang Eun, was originally published Online First without Open Access. After publication in volume 29, issue 4, pages 449-458 the author decided to opt for Open Choice and to make the article an Open Access publication. Therefore, the copyright of the article has been changed to (C) The Author(s) 2020 and the article is forthwith distributed under the terms of the Creative Commons Attribution 4.0 International License (http://creativecommons. org/licenses/by/4.0/), which permits use, duplication, adaptation, distribution and reproduction in any medium or format, as long as you give appropriate credit to the

The original article can be found online at https:// doi.org/10.1007/s10068-020-00755-1.

Jong-Bang Eun

jbeun@jnu.ac.kr

Thinzar Aung

junothinzar88@gmail.com

Marie Anna Dominique Bibat

madrbibat@gmail.com

Chang-Cheng Zhao

changchengzhao91@gmail.com

1 Department of Integrative Food, Bioscience and Biotechnology, Graduate School of Chonnam National University, Gwangju 61186, South Korea original author(s) and the source, provide a link to the Creative Commons license, and indicate if changes were made.

The original article has been corrected.

Open Access This article is licensed under a Creative Commons Attribution 4.0 International License, which permits use, sharing, adaptation, distribution and reproduction in any medium or format, as long as you give appropriate credit to the original author(s) and the source, provide a link to the Creative Commons licence, and indicate if changes were made. The images or other third party material in this article are included in the article's Creative Commons licence, unless indicated otherwise in a credit line to the material. If material is not included in the article's Creative Commons licence and your intended use is not permitted by statutory regulation or exceeds the permitted use, you will need to obtain permission directly from the copyright holder. To view a copy of this licence, visit http://creativecommons. org/licenses/by/4.0/.

Publisher's Note Springer Nature remains neutral with regard to jurisdictional claims in published maps and institutional affiliations. 